International Journal of Linguistics, Literature and Culture
Available online at https://sloap.org/journals/index.php/ijllc/
Vol. 7, No. 2, March 2021, pages: $82-89$
ISSN: 2455-8028
https://doi.org/10.21744/ijllc.v7n2.1353

\title{
The Vietnamese Greetings in Mekong Delta, Vietnam
}

Dan Tam Thi Nguyen ${ }^{\text {a }}$ Cuong Le Khac ${ }^{b}$

Article history:

Submitted: 27 Dec 2020

Revised: 09 Jan 2021

Accepted: 18 Feb 2021

\section{Keywords:}

culture; greetings; identity;

\begin{abstract}
From long time ago, the Vietnamese have had the saying: 'Lời chào cao hơn mâm cố ${ }^{\mathrm{c}}$. It implied that a greeting was highly respected than being invited to enjoy a big meal although food was very rare after the wars in Vietnam. It is likely to show that greeting culture in Vietnam is not only for communication but also for the assessment of individuals' behaviour background. Today, in the era of technology, a greeting may create a friendlier feeling to help people become closer. This qualitative study explored how residents in Mekong Delta of Vietnam greeted each other in daily life. Their greetings reflect their identities and the culture of the community.
\end{abstract}

International journal of linguistics, literature and culture (C) 2021. This is an open access article under the CC BY-NC-ND license (https://creativecommons.org/licenses/by-nc-nd/4.0/).

\section{Corresponding author:}

Nguyen, D.T.T.

A lecturer of English at Hong Bang International University, Vietnam

Email address: tamntd@hiu.vn

\footnotetext{
${ }^{a}$ Hong Bang International University, Ho Chi Minh City, Vietnam

${ }^{b}$ Hong Bang International University, Ho Chi Minh City, Vietnam

${ }^{c}$ A greeting is much better than a big meal.
} 


\section{Introduction}

Language is the most important tool for human communication. Thanks to language, each individual can exchange information, express themselves, and establish relationships with everyone. However, before coming to a real conversation, access should be done to direct to it to attract the interlocutors and address them properly. The ritual speech which includes greeting, making acquaintance, saying goodbye, congratulating, thanking, apologizing, consulting, requesting, and inviting has the function to establish the interactional relationship among the interlocutors. That function is likely to be presented the most clearly through greeting culture. The greeting is very essential in our lives because it is politeness whose relevance to all of the relationships. Therefore, greeting culture is one of the most important aspects and shows mutual respect.

\section{Literature Review}

\section{Definitions}

'Greetings are among the first speech acts that are learned by children in their native languages' (Gass, 1995). To greet means to welcome someone with a particular word or particular action, or to react to something in a stated way (Cambridge Advanced Learners' Dictionary). To Nguyen (1999), greeting means speaking or miming with acts to show respect and friendliness. For the Vietnamese Linguistics Association (1999), Vietnamese greetings are affected by Confucianism, so greeting culture is much more emphasized. It was constructed thousands of years ago, dated from agriculture. Therefore, Vietnamese greetings are very honest, friendly, and abundant, and the impact of power and solidarity can be seen by looking at greeting specifically.

Hofstede defines power distance as "the extent to which the less powerful members of institutions and organizations within a country expect and accept that power is distributed unequally" (via the internet), so it may show through greetings.

\section{Greetings used in the communities}

To examine greetings, Bjørge (2007) conducted an interesting study about greetings affected by power distance by examining hundreds of emails. She carefully looked at the data from high power distance countries such as China, France, and Vietnam, and low power distances ones like Britain, Canada, and Israel. Expectedly, all of the students from high power distance countries chose the most formal greetings in their emails, addressing tutors with 'Dear+ Title+ Surname'. She also finds that nonnative speakers have a wider range of greetings than that of the native because of the influence of mother tongue when translating and due to level of English proficiency.

Also looking at the written type of greetings in emails occurring at the workplace, Waldvogel (2007) investigated the emails between an educational organization and a manufacturing plant in New Zealand. The findings show that there were much more greetings to open emails in the manufacturing plant than that in the educational organization. The author explains two reasons. Firstly, it was because of the more familiar working environment. Secondly, doing business was the first target in the plant, so greeting customers created the habit of greetings frequency in their emails. Regarding the less use or the absence of greetings at the educational organization, the author suggests it may reflect the social distancing strategies people use when they feel alienated from what is going on'. Moreover, it might be assumed that the managers received a large number of emails every day, so replying to such an amount would make them work under pressure. Another possibility was that they are unnecessary in exchanges among professionals engaged in a common purpose'. From the analysis, he says that it was the working culture that affected the greetings, not the power and solidarity.

Similarly, Hao et al. (2008) did a comparative study on how American and Chinese students addressing others in greetings. She finds that when the Chinese students were in China, they used to greet others by last names or title + first names, but when they studied in the USA, they began to address with the first name or even no name when greeting. A fact that may surprise readers is that she finds the Chinese students address the older people with nicknames, informally.

Nguyen, D. T., \& Le Khac, C. (2021). The Vietnamese greetings in Mekong Delta, Vietnam. International Journal of Linguistics, Literature and Culture, 7(2), 82-89. 


\section{Types of greetings around the world}

Being different from the research above, Duranti (1997) analysed the spoken greetings exchange in Western Samoa. He finds that the Samoan had four types of greetings. The first one was greetings accompanied with hand shaking and miming. The second was showing sympathy to the greeters, but not greeting. The third was a kind of wishing greeting, and the last type was ceremonial greetings which are used when key figures came or are used in some events. Among those four types, he highlights the 'where-are-you-going?' greeting type. He says that it cannot be analysed as an expressive type of speech acts because 'it is an attempt to sanction the reciprocal recognition of one another's presence with some specific requests of information they may or may not receive the satisfactory response'.

Contributing to research on spoken greetings, Jucker et al. (2008) looked at the differences between the ancient and modern English greetings. The result shows that the greeting function has been changed. In the past, the 'assertive' and 'expressive' functions used to be separated from each other, but in today greetings, these two functions co-exist together, so the addressee has a choice to interpret the sentence: 'where are you going?' as a greeting or an information question. In addition, he realizes that ancient greetings are usually complete and transparent whereas the modern ones prefer to be deviant and opaque which should be understood with some presuppositions. Another difference is that the old greetings have the desire for vivid expression and flattery while the new ones try to avoid excessive length.

Gass (1996) also did a study about American spoken greetings. He admits that greeting can consist of a single speech act or a speech act set. He labels greetings into several types: greeting on the run (exchanging brief phatic statements or questions which do not necessarily require responses), speedy greeting (information is exchanged), the chat (a short discussion on a topic or two before either leave-taking or the real purpose of the communication is introduced), the long greetings (re-establishing bonds between two people after a period of separation), the intimate greeting (greeting occurs between people who know each other well and speak frequently), all-business greeting (is sometimes characterized with a very short preliminary greeting or, sometimes, no greeting at all), introductory greeting (greeting between two people who are meeting for the first time), and re-greeting (acknowledging someone you have greeted earlier or see repeatedly during the day.) From all of the previous research, a small study of how the Vietnamese greet each other and how power and solidarity influence on greetings should be made to be compared.

\section{Research Questions}

In this essay, I would like to find the answer for these questions: (1) How do Vietnamese people in the South of Vietnam greet each other? (2) How do power and solidarity influence the greeting styles?

\section{Participants}

Most of the participants in this research are members in my family. They are my parents, younger sister, daughter and some of my relatives who live next door. In addition, some others are my friends who lives about 5 kilometers away from my house. I am the participant-observer. All of the participants are in Mekong Delta which belongs to the South of Vietnam. They are the Kinh who are the original Vietnamese beside the Khmer (Cambodian Vietnamese) and the Hoa (Chinese Vietnamese) in this city.

\section{Research Method}

With the desire to keep the greeting natural, especially greetings that usually happen at the beginning of the conversations, I did not inform the time to record the greeting. I only told my family that I would write an essay about greetings, so their greetings would be collected into my essay. The greetings were collected in three days after I had been back to Vietnam. The data were in two types: notes and voice recording. I started to collect the data as soon as I reached home. On the next day, I brought the voice recorder with me when I visited my relatives. However, on the last day, I took notes. Then the neighbours came to talk to my relatives after greeting me. Therefore, I sat at the corner of the house to listen and took notes. After that, the transcript was made in Vietnamese with original 
Vietnamese tone marks. Finally, they were translated into English. I tried my best to keep the exact meaning when translating.

The advantage of this method is the convenience to get data because the participants are my family members and friends. They live in the same community, so I found it easy to get access to the data. Moreover, family relationships tend to present the influence of power and solidarity rather clearly through greetings. However, the disadvantage is the limited styles of greetings as they are Vietnamese in the southern region, so their greetings have the southern styles' characteristics which are less formal than that in the North or the Middle. Another disadvantage is the Vietnamese transcript which took a great deal of time to translation.

\section{Results}

The Vietnamese language has many different ways to indicate the first pronoun such as 'con', $\boldsymbol{c h a ́ u , ~ e m , ~} \boldsymbol{c h i ̣}$ '... as well as the second pronoun like 'c $\hat{\boldsymbol{o}}^{\boldsymbol{e}}$, $\boldsymbol{d} \boldsymbol{i}$, $\boldsymbol{c h} \boldsymbol{h}$, bác'... The Vietnamese are highly concerned the family order, so they use personal pronouns in every greeting to emphasize that order. The first and second pronouns can be used as both the speakers and listeners, depending on the contexts.

\subsection{Direct greeting}

The direct greeting concludes the main verb 'chào'. When the speakers use this style, they will act at the same time. Usually, it is a bow or a handshaking. The structure can be like this: Chào+ listener; or Speaker+chào+ listener. In this research, this type happened among family members, friends and I.

28- Chào ${ }^{\mathrm{f}} \mathrm{em}$.

42- Chào chị.

37- Chào chị T.

35- Em chào chị $\mathrm{T}$.

39- Chị chào em.
- Hello, little sister.

- Hello, older sister.

- Hi, sister T.

- I say hello to you, sister T.

- I say hi to you, little sister.

\subsection{Indirect greeting}

There are many ways of direct greetings. They are asking, greeting by addressing names and exclaiming, wishing, inviting and committing. Although it may mean a different message in another language, it has an identical function which is to greet in Vietnam.

\section{a) Greeting by asking}

The Vietnamese usually have the habit to greet by asking about the work which the listener is doing at that moment. Indeed, the speakers do not expect to receive the answers. To them, asking shows their concerns and cares which can lead to closer social relationship. The common topics are about family, work, and health, depending on how close the speakers and listeners are. Therefore, in order to respond to this type of greeting, the listeners can mime (nodding head, smiling...) or raising another question. The following extracts were cited from the conversations among several neighbours and I. Some of them knew I studied in England, some did not know. Therefore, when they met me, they had different questions:

41- Về hồi nào vậy chị? - When did you return, older sister?

18- Về hồi nào vậy con? - When did you return, grandchild?

20- Con về lúc nào vậy? - When did you come back, niece?

22- Con mới về à? - Grandniece, you have just come back, haven't you?

24- Sao lâu rồi bác không gặp con? - Why hasn't aunt seen you for a long time, niece?

26- Con mới đến chơi à? - Have you just come, niece?

41- Bộ chị học xong rồi sao? - Did you finish your programme, older sister?

31- Chị đi đâu đấy?

- Older sister, where are you going?

d Con, cháu, em, chị= I. It depends on the family relationship and order. Con= a child; cháu= niece/ nephew; em= younger sister; chị= older sister

e Cô, dì, chú, bác= You. It depends on the family relationship and order. Cô= miss, or father's sister; dì= mother's sister; chú= father's younger brother; bác= father older brother

f Chào= hi, hello

Nguyen, D. T., \& Le Khac, C. (2021). The Vietnamese greetings in Mekong Delta, Vietnam. International Journal of Linguistics, Literature and Culture, 7(2), 82-89. https://doi.org/10.21744/ijllc.v7n2.1353 
37- Ăn cơm chưa mà lại đây đây? - Have you had meals before coming here?

\section{b) Greeting by addressing names and exclaiming}

This greeting style often expresses excitement, surprise and happiness of the speaker when the listener suddenly appears. In addition to the exclamation, the eye contact, a clap, or a wave are used to increase the communication effect. In the conversations collected, there were a lot of eye contact and hugs added to the greetings.

32 - Trời! Về khi nào vậy $\mathrm{T}$ ? - Gosh! When did you return, T?

42- Ủa, T về rồi à?

42- Ủa, sao T về sớm vậy?

41- Trời ơi, chị $\mathrm{T}$ về kìa.

1- A, má mi về, má mi về!

- Oh, T, you have returned, haven't you?

- Oh, why did you return so early, T?

- My goodness, sister T is coming back.

- Aaaaah, here comes Mom!

c) Greeting by wishing

This style is used when two communicators knew the presupertition before. This usually happens among relatives or close friends or among anyone who remains the contact with each other regularly.

27 - Chúc mừng được về thăm con nhe. - Congratulate on being back to visit your kid!

44- Chúc mừng chị nhe. - Congratulations, older sister!

3- Mừng má mi đã về. - Congratulations on coming back, mom!

\section{d) Greeting by inviting}

In Vietnam, an invitation when speaking means greetings. Usually, the speakers invite the listeners to have some drink or even a meal if they are having meals when guests come. That is the hospitality of the Vietnamese. The best response would be a refusal and thank to the invitation.

29 - Vào đây chơi con. - Please come in, niece.

46- Mời chị vào uống nước. $\quad$ - Please come in to have a drink, sister.

28- Vào đây ăn chén cơm con. ㄴ - Please come in to have a bowl of rice, niece.

32- Hôm nào rảnh đi uống cà phê nhe. - Let's go to the coffee shop when having time.

44- Hôm nào lại nhà em chơi nhe. - - Please come to my house when you have time.

\section{e) Greeting by committing}

A commitment in Vietnam can be used for greeting. This shows the speaker's concern with the listener. In Vietnam, it is very common to give commitment for the one's skin because the bright or white skin is the most admirable in the sunny country.

42- Trời, sành điệu quá ta.

16- Phải công nhận chị trắng quá trời

39- Ai mà trắng quá vậy ta?

44- Chà, giống Việt kiều lắm rồi.

7- Ờ. Ốm quá vậy con?

- Oh, God! How posh you are!

- I have to admit that your skin is so bright!

- Oh, whose bright skin is it?

- Well, you look like an over-sea Vietnamese

- All right. Why did you lose weight so much, darling?

now really.

\subsection{Greetings between lower and higher interlocutors in power and solidarity}

Because the Vietnamese focus on the order through greetings, the lower interlocutor in terms of power and solidarity usually use direct greeting to higher interlocutor. It indicates clearly 'who greets whom'. Beside, 'thua, $\boldsymbol{a}$, $\boldsymbol{h} \hat{\boldsymbol{a}} \boldsymbol{u}^{\text {'g }}$ are added in every greeting to show the lower position and politeness. Using that style, children have to bind their arms in front of chests and bend down whereas adults can nod their heads and bend down also. In terms of power and solidarity, the lower must greet the higher communicator first. It shows the politeness and respect.

6- Thua ba mẹ con mới về. $\quad$ - Dad and Mom, I have been back.

2- Con chào má mi $\boldsymbol{a}$.

10- Hầu bà ngoại con mới qua.

- I welcome you, Mom.

- Grandma, I have just arrived.

$\mathrm{g}$ Thưa, hầu, a $=$ state adverbs which show the high respect of the speaker to the listener. 
14- Em chào chị $\boldsymbol{a}$. - I say hi to you, older sister.

\subsection{Greetings between equal interlocutors in power and solidarity}

The direct greeting is also used among equal communicators in power and solidarity, but it does not include the words 'thưa, hầu, ạ'. It seems similar to that in English such as: Hello, John or Good morning.

40- Chào L.

40- Chào anh Th.

31- Chào chi K.

15- Chào bé Kh. Cưng mới đi học về à? - Hi, little Kh. Have you just finished classes?

- Hi Lan.

- Hello brother Th.

- Hi sister K.

\subsection{Greetings between higher and lower interlocutors in power and solidarity}

As being said above, the Vietnamese concern about the order in society. When being greeted by the less power and solidarity interlocutors, the higher ones usually have very short response, meaning 'yes'. Yet, in most cases, they usually smile back or nod head instead of saying some greetings.
45 - Chào con.
11- Ùm.
4- Ò̀.
11- Ửm. Con về hồi nào?
- Yes.
- Hello, niece.
- All right.
- Yes. When did you come back?

\section{Discussion}

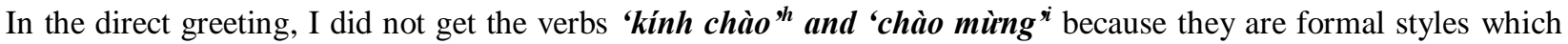
are preferred in meetings and on television programmes. However, the indirect one reflects remarkably the life of community where caring and sharing is the major feature. This differs from that in British culture which emphasizes on privacy. Therefore, there was a funny story about a Dutch scientist who came and lived in the countryside in Vietnam.

'A farmer met him and greeted:

- Uncle John, where are you going?

- Oh, go straight, he replied.

(Hoi ngon ngu hoc Vietnam, 1999)'

That was because he did not know about the function of a 'question greeting'. However, the wishing greeting is similar to that in English because adjectives are usually used together with nouns to create greeting. For instance, 'good morning, good afternoon, and happy working'. Contributing to the interesting features of Vietnamese greeting, the commitment greeting not only pleases the listeners but also remains the good relationship possibly. Because of those all features, greetings can be a type of measurements of how well- educated a communicator is.

In Vietnam, men tend to direct the greetings to work while women focus on family, children, clothes and hair styles. Depending on the relationship, the greetings would be less or more specific. Asking for health is only used for elderly people because the Vietnamese think that elderly people badly need health in this stage. On opposition, the young have the tendency to use wishing and inviting greeting as they expect for potential promotion, and a lot of work or contracts can be done at an event or party after the random inviting greeting. Due to the complexity of Vietnamese greetings, they prefer to use English to simplify greetings such as: 'Hello Lan. / Hi em! Hé lô (Hello)'. Another difficulty is that because the busy life, the Vietnamese parents have the tendency to neglect to teach the greeting cultures to their children. Therefore, it seems to be common seeing children or students not to greet other people. If greetings between less power and more power interlocutors or vice versa have the significant signals and rather formal, that one in equal power is very casual, flexible and informal with many styles of body language, basing on the speakers' personalities.

The result is in agreement with Bjørge (2007) in terms of power and solidarity as the Vietnamese use personal

h Kính chào= to greet respectably

i Chào mừng $=$ welcome

Nguyen, D. T., \& Le Khac, C. (2021). The Vietnamese greetings in Mekong Delta, Vietnam. International Journal of Linguistics, Literature and Culture, 7(2), 82-89. https://doi.org/10.21744/ijllc.v7n2.1353 
pronouns in most of the greetings to emphasize the social order. Although Vietnamese greetings are strongly affected by power and solidarity, they also share the idea with Waldvogel (2008). If the greetings in his research are influenced by the workplace culture, the Vietnamese greetings are affected by the living area, the life of community where people live next to each other and consider neighbours as family members. However, there is a remarkable difference if comparing with the research of Hao et al. (2008). In her work, the Chinese address older people by nicknames informally while the Vietnamese always do the opposite to show respect and politeness. The result also differs from that of Duranti (1997) because in Vietnam, not greeting in response means showing the power with the greeters, not showing sympathy. Yet, the result supports him that the 'where-are-you-going' greeting is not necessary to reply. That point also agrees with Jucker et al that the 'where are you going' greeting can be interpreted as 'assertive' and 'expressive'. Finally, although the form and styles of the Vietnamese greetings may differ from that in Gass's research (1996), their communication functions are similar.

\section{Conclusion}

I have just presented some basic greetings when the Vietnamese meet each other and communicate. It is likely to see that not only do the structures of greetings have to follow the linguistic rules but also do they have to be set by the arbitrary rules of specific rules of communication feature the community. It would be more sufficient if I have more space to explain more about the roles of greetings in different relationships in terms of the communication purposes, contexts, contents, and channels, especially having the data access to the greetings in the North and the Middle. Again, a greeting is a means to establish and maintain social relationships and is a beautiful act of culture. Therefore, keeping greeting culture in the process of exchanging cultures, intercultural and cultural influences is a duty of each individual.

\section{Biodata}

Dr. Dan Tam Thi Nguyen is a lecturer of English at Hong Bang International University, Vietnam

Associate Professor Cuong Le Khac is the Dean of the Faculty of Social Sciences and International Languages at Hong Bang International University, Vietnam

\section{Conflict of interest statement}

The authors declared that they have no competing interests.

\section{Statement of authorship}

The authors have a responsibility for the conception and design of the study. The authors have approved the final article.

\section{Acknowledgments}

We are grateful to two anonymous reviewers for their valuable comments on the earlier version of this paper. 


\section{References}

Bjørge, A. K. (2007). Power distance in English lingua franca email communication 1. International Journal of Applied Linguistics, 17(1), 60-80. https://doi.org/10.1111/j.1473-4192.2007.00133.x

Duranti, A. (1997). Universal and culture-specific properties of greetings. Journal of linguistic Anthropology, 7(1), 63-97. https://doi.org/10.1525/jlin.1997.7.1.63

Gass, S., \& Neu, J. (Eds.). (2009). Speech acts across cultures: Challenges to communication in a second language (Vol. 11). Walter de Gruyter.

Hao, S., Zhang, S., \& Zhu, F. (2008). A Comparative study of Chinese and American address terms. Journal of Praxis in Multicultural Education, 3(1), 3.

Hội ngôn ngữ học Việt Nam. 1999. Ngũ học trẻ'99. Nghệ An.

Jucker, A. H., \& Taavitsainen, I. (Eds.). (2008). Speech acts in the history of English (Vol. 176). John Benjamins Publishing.

Nguyễn, N. Y.1999. Tù điển Tiếng Việt. Nhà xuất bản giáo dục. ${ }^{k}$

Waldvogel, J. (2007). Greetings and closings in workplace email. Journal of Computer-Mediated Communication, 12(2), 456-477. https://doi.org/10.1111/j.1083-6101.2007.00333.x

http://www.geert-hofstede.com/ Accessed on April 6, 2019, 15:33

j The Vietnamese Linguistics Association. 1999. The Young Linguistics, Issue 99.

k Vietnamese Dictionary. House of Educational Publication

Nguyen, D. T., \& Le Khac, C. (2021). The Vietnamese greetings in Mekong Delta, Vietnam. International Journal of Linguistics, Literature and Culture, 7(2), 82-89. https://doi.org/10.21744/ijllc.v7n2.1353 